\title{
GNG12 wt Allele
}

National Cancer Institute

\section{Source}

National Cancer Institute. GNG12 wt Allele. NCI Thesaurus. Code C114335.

Human GNG12 wild-type allele is located in the vicinity of 1 p31.3 and is approximately 132 $\mathrm{kb}$ in length. This allele, which encodes guanine nucleotide-binding protein $\mathrm{G}(\mathrm{I}) / \mathrm{G}(\mathrm{S}) / \mathrm{G}(\mathrm{O})$ subunit gamma-12 protein, is involved in GT Pase-dependent signaling. 